DOI: 10.4274/tpa.45.272

\title{
Erken ve zamanında doğmuş bebeklerin anne sütlerinin çinko, bakır ve demir düzeylerinin karşılaşııııması
}

\section{The comparison of zinc, copper and iron concentration in preterm and term babies mother's milk}

\author{
Ayşe Betül Ergül, Mehmet Adnan Öztürk* Zeliha Leblebici** \\ Kayseri Eğitim ve Araştırma Hastanesi, Çocuk Kliniği, Kayseri, Türkiye \\ *Erciyes Üniversitesi Tıp Fakültesi, Çocuk Sağlığı ve Hastalıkları Anabilim Dalı, Kayseri, Türkiye \\ ***Erciyes Üniversitesi Tıp Fakültesi, Biyoloji Anabilim Dalı, Kayseri, Türkiye
}

\begin{abstract}
Özet
Amaç: Kayseri'de doğan erken ve zamanında doğmuş bebeklerin anne sütlerinin bakır, çinko ve demir düzeylerini belirlemek, anne sütlerinin bebeklerin çinko, bakır ve demir gereksinimlerinin ne kadarını karşıladığını saptamak, bu elementlerin sütteki düzeyi ile laktasyon zamanı, erken doğma ve bebeklerin gestasyonel yaşı arasında ilişki olup olmadığını belirlemektir.

Gereç ve Yöntem: Çalışmamızda, 47'si erken ve 41'i zamanında doğmuş olan 88 bebeğin annesinden laktasyonun farklı üç döneminde alınmış olan anne sütü örnekleri kullanıldı. Erken doğmuş bebekler kendi aralarında gestasyonel yaşlarına göre 28-30, 30-32, 32-34 ve 34-36 haftalık olarak dört gruba ayrıldı. Süt örneklerinin bakır, çinko ve demir düzeyleri ICP (Inductively Coupled Plasma) Spektroskopi cihazı ile mg/L olarak ölçüldü.

Bulgular: Kayseri'de yaşayan zamanında ve erken doğmuş bebeklerin anne sütlerinin bakır içeriği literatüre göre belirgin olarak düşük bulundu. Laktasyonun ilerlemesi ile anne sütünün bakır, çinko ve demir içeriğinde azalma tespit edildi. Erken doğmuş bebeğin anne sütünün kolostrumunun bakır düzeyi zamanında doğana göre anlamlı olarak daha yüksek bulundu. Erken doğmuş bebeklerin anne sütleri gestasyonel yaşlarına göre karşılaștırıldığında, 28-30 haftalık grubun kolostrumunun bakır düzeyi diğer erken doğmuş bebek gruplarınkine göre anlamlı olarak daha düşük bulundu. Çinko düzeyi ise laktasyonun her üç döneminde 28-30 haftalık grupta diğer gruplara göre daha yüksek olarak bulundu. Çıkarımlar: Kayseri'de erken doğmuş bebeklerin anne sütlerinin bakır, çinko ve demir düzeyleri bu bebeklerin günlük gereksinimlerine göre düşüktür. Anne sütü ile beslenen bu bebeklere bakır, çinko ve demir desteği yapılması gerekmektedir. 28-30 haftalık bebeklerin anne sütlerinin çinko düzeyi diğer erken doğmuş bebeklere göre daha yüksektir. Bu özellik çinkonun büyüme ve gelişme üzerine olan olumlu etkileri ile ilişkili olabilir ve ileri derecede erken doğmuş bebekler için hazırlanacak formül mamalarda dikkate alınabilir. (Türk Ped Arş 2010; 45: 272-9)

Anahtar sözcükler: Bakır, çinko, demir, erken doğmuş bebeğin anne sütü, laktasyon dönemi, zamanında doğmuş bebeğin anne sütü
\end{abstract}

\section{Summary}

Aim: To compare and to determine the copper, iron and zinc concentrations in preterm and term human milk and to determine if the human milk is enough for the requirements of zinc, copper and iron in babies, and to determine the relationship between the concentrations of these elements in milk and lactation time, prematurity, and the gestational age of the babies.

Material and Method: 47 mothers of preterm and 41 mothers of term babies, a total of 88 mothers were involved in this study. Three milk samples were collected from each mother in the different periods of lactation. The preterm group was divided into four groups: 28-30 wks, 30-32 wks, 32-34wks and 34-36 weeks. The copper, iron and zinc concentrations of the human milk samples were measured as mg/L using Inductively Coupled Plasma Atomic Emission Spectroscopy.

Results: Concentration of copper in breast milk of the mothers living in Kayseri were significantly lower than the mothers living in developed countries. Zinc, copper and iron concentrations of breast milk decreased during the lactation time. Preterm colostrum copper concentration was lower than term colostrum copper concentration. The copper concentration of the preterm groups whose gestational age were $28-30$ weeks were lower than the others. The zinc concentration of the 28-30 weekly preterm group was higher than the other groups in all periods of lactation.

Conclusions: Calculated daily intakes of zinc, copper and iron for preterm infants from preterm milk in Kayseri were markedly lower than those of Recommended Dietary Allowances. To prevent zinc, iron and copper deficiency, the preterm infant's breast milk should be suplemented by zinc, iron and copper. The zinc levels of 28-30 weeks preterm group's breast milk was higher than the other preterm groups. This speciality can be related by development and growth effects of zinc. (Turk Arch Ped 2010; 45: 272-9)

Key words: Copper, iron, lactation time, preterm breast milk, term breast milk, zinc

Yazışma Adresi/Address for Correspondence: Dr. Ayşe Betül Ergül, Kayseri Eğitim ve Araştırma Hastanesi, Çocuk Kliniği, Kayseri, Türkiye E-posta: abergul@hotmail.com Geliş Tarihi/Received: 18.01.2010 Tarihi/Accepted: 09.06.2010 


\section{Giriş}

Sağlıklı yenidoğan bir bebeğin ilk altı ay sadece anne sütü ile beslenmesi gerektiğini düşünürsek, anne sütünün çinko $(\mathrm{Zn})$, bakır $(\mathrm{Cu})$ ve demir $(\mathrm{Fe})$ yoğunluğunun bilinmesi, eser elementlerin yeterli oranda alınıp alınmadığının tespit edilmesi ve bebeklere destek yapılmasının gerekip gerekmediğinin belirlenmesinde önemlidir. Anne sütünün eser element düzeyi ülkelere göre belirgin farklılık göstermektedir. Örneğin Nakamori ve ark.'larının (1) Vietnam'da yapmış oldukları çalışmada zamanında doğmuş bebeklerin anne sütünün $\mathrm{Cu}$ düzeyi $0,19 \pm 0,05 \mathrm{mg} / \mathrm{L}$ olarak bulunurken, Ohtake ve ark.' 'larının (2) Japonya'daki çalışmasında 0,35 $\pm 0,14$ mg/L; Dömellöf ark. 'larının (3) İsveç'deki çalışmalarında zamanında doğmuş bebeklerin anne sütünün $\mathrm{Fe}$ düzeyi $0,29 \pm 0,21 \mathrm{mg} / \mathrm{L}$ olarak bulunurken, Yamawaki ve ark.'larının (4) Japonya'daki çalışmasında 1,19 $\pm 2,51$ mg/L; Dhonukshe-Rutten ve ark.' 'arının (5) Guatemala'daki çalışmasında term bebeklerin anne sütünün $\mathrm{Zn}$ düzeyi 2,03 $(0,47-6,19) \mathrm{mg} / \mathrm{L}$ olarak bulunurken, Sharmel ve ark.'larının (6) Almanya'daki çalışmasında 16,0 $\pm 5,5 \mathrm{mg} / \mathrm{L}$ olarak bulunmuştur. Anne sütünün $\mathrm{Cu}, \mathrm{Zn}$ ve $\mathrm{Fe}$ yoğunluğunun anne diyetinden etkilenmediği bilinse de $(1,3)$ yapılan çaış̧malarda birbirinden oldukça farklı sonuçların bulunması anne sütünün eser element içeriği üzerinde coğrafi farklıllğın etkisinin belirgin olduğunu düşündürmektedir (7).

Çalışmamızda Kayseri'de yaşayan annelerin sütlerinin $\mathrm{Cu}, \mathrm{Zn}$ ve Fe içeriği ve bebeklerin anne sütü ile beslendiklerinde bu elementleri yeterli oranda alıp almadıklarının belirlenmesi hedeflendi.

Kolostrumun içeriği yenidoğan bir bebeğin ilk günlerindeki gereksinimlerine uygun nitelikte olduğundan dolayı geçiş sütü ve olgun süte göre belirgin farklılık göstermektedir (8). Çalışmamızda kolostrum $\mathrm{Cu}, \mathrm{Zn}$ ve Fe içeriği açısından geçiş sütü ve olgun süt ile karşılaştıııldı. Kolostrumun bu elementler açısından oldukça kıymetli olduğu vurgulanmaya çalışıldı.

Erken doğmuş bebeğin anne sütünün içeriği meme dokusunun fizyolojik, metabolik ve endokrin olarak olgunlaşmamış olmasından dolayı zamanında doğan bebeğin anne sütüne göre farklılık göstermektedir $(9,10)$. Çalışmamızda bu iki grup bebeğin anne sütleri $\mathrm{Cu}, \mathrm{Zn}$ ve Fe içerikleri açısından karşılaştıııldı. Ayrıca gestastonel yaşa göre anne sütünün içeriği değişebildiğinden $(11,12)$ eser elementler hakkında yapılmış olan önceki çalışmalardan farklı olarak çalışmamızda bebeklerin gestasyonel yaşları da dikkate alındı.

\section{Gereç ve Yöntem}

Aralık 2005 ve Ekim 2006 tarihleri arasında Erciyes Üniversitesi Tıp Fakültesi Kadın Doğum Kliniği'nde doğan 47 'si erken ve 41 'i zamanında doğmuş olan 88 bebeğin anne sütü örnekleri bu çalışmada kullanıldı. Gestasyonun
37. haftasından önce doğan bebeklere erken doğmuş denildiğinden çalışmamızda 37 haftanın altında doğanlar bu grupta değerlendirildi. Zamanında doğmuş bebekler gruba 37 hafta ve üzerinde doğan bebekler alındı. Erken doğan bebekler Ballard skorlama sistemi kullanılarak belirlenen gestasyonel yaşlarına göre 28-30, 30-32, 32-34 ve 34-36 hafta olmak üzere dört gruba ayrıldı. 28-30 haftalık grup için 10, 30-32 haftalık grup için 12, 32-34 haftalık grup için 10, 34-36 grup için 15 bebeğin annesinden allnan süt örnekleri çalışmaya alındı. Anne sütünün $\mathrm{Fe}, \mathrm{Zn}$ ve $\mathrm{Cu}$ içeriğinin anne diyetinden etkilenmediğini gösteren daha önceki çalışmalara dayanılarak $(1,3,6)$ annelerin beslenme özelliğine ait bilgi alınmadı.

Her bebeğin annesinden kolostrum, geçiş sütü ve olgun süt olmak üç farklı zamanda süt örneği alındı. Kolostrum sütü doğumdan sonra ilk 3 gün, geçiş sütü 7-14 gün, olgun süt ise 30-40 gün arasında alındı. Toplam 264 süt örneğinin $\mathrm{Cu}, \mathrm{Zn}$ ve Fe içeriğine bakıldı.

Süt örnekleri günün herhangi bir saatinde, emzirmeden en az yarım saat önce, her iki göğüsten elle sağılarak en az $3 \mathrm{ml}$ olmak üzere deiyonize edilmiş polietilen tüpler içerisine alındı. Süt örneği alınmadan önce annenin göğsü deiyonize su kullanılarak temizlendi. Örnekler çalışma yapılana kadar $-20 \mathrm{C}$ derecede saklandı.

Sütlerin organik kısmını ayırma işlemi için sütler oda ısısında çözüldükten sonra homojen hale gelene kadar karıştırıldı. Her süt örneğinden $0,5 \mathrm{ml}$ alınarak deiyonize edilmiş teflon tüplere konuldu. Üzerine 9:1 oranında nitrik ve perklorik asitten oluşan sıvıdan $9 \mathrm{ml}$ ilave edildi. Örnekler CEM marka Marsh mikrodalga firında 300 PSI basınçta 20 dakika içinde 210 dereceye kadar Isıtıldıktan sonra soğumaya bırakıldı. Sonra tüplerin ağzı açılarak nitrik asitten oluşan buhar çıkarıldı. Organik kısmından ayrımış ve berrak hale gelmiş süt örnekleri deiyonize polietilen tüpler içinde deiyonize su kullanılarak 10 kat sulandırıldı ve analize kadar $-4 \mathrm{C}$ derecede sakland.

Süt örneklerinin $\mathrm{Zn}, \mathrm{Cu}$, Fe içeriğinin ölçümü için Varian marka ICP (Inductively Coupled Plasma) Spektroskopi cihazı kullanıldı. Standart sıvıların alette okutulması ile standardizasyon sağlandıktan sonra Fe 259,940; Cu 327,754; Zn 206,200 dalga boyunda ölçüldü. İstatistiksel analiz Statistical Package for Social Scienses (SPSS) for Windows 13.0 paket programı kullanılarak yapıldı. İki grup bebek annelerinin laktasyonun farklı üç zamanında alınan sütlerinin $\mathrm{Cu}, \mathrm{Zn}$ ve Fe ölçüm değerlerinin karşılaştııılmasında Mann Whitney-U testi, erken doğmuş bebek grubunun gestasyonel yaşa göre oluşturulmuş dört farklı alt grubunun $\mathrm{Cu}, \mathrm{Zn}$ ve Fe ölçüm değerlerinin karşılaştırımasında Kruskal Wallis varyans analizi, erken ve zamanında doğmuş bebek grubun sütlerinin $\mathrm{Cu}$, $\mathrm{Zn}$ ve Fe ölçüm değerlerinin karşılaştııımasında Friedman testi kullanıldı. Sonuçlar ortanca (minimum-maksimim) şeklinde verildi. Tüm testlerde $p<0,05$ değerleri anlamlı olarak kabul edildi. 
Erken ve zamanında doğmuş bebeklerin anne sütlerinin $\mathrm{Cu}, \mathrm{Zn}$ ve $\mathrm{Fe}$ düzeyi belirlendikten sonra anne sütlerinin bebeklerin günlük gereksinimlerinin yani RDA'nın (Recommended Dietary Allowance) ne kadarını karşıladığı yüzde olarak hesaplandı.

\section{Bulgular}

Laktasyon zamanı ile anne sütünün $\mathrm{Cu}$, Fe ve $\mathrm{Zn}$ içeriğindeki değişim incelendiğinde, kolostrumun $\mathrm{Cu}$, Fe ve $\mathrm{Zn}$ düzeyi, geçiş sütüne ve olgun süte göre daha yüksek olarak bulundu. Laktasyonun ilerlemesi ile $\mathrm{Zn}$ düzeyindeki azalma Cu ve Fe göre daha belirgindi (Tablo 1).

Erken ve zamanında doğmuş bebek grubunun anne sütlerinin $\mathrm{Cu}, \mathrm{Zn}$ ve $\mathrm{Fe}$ düzeyleri karşılaştıııldığında, $\mathrm{Cu}$ düzeyi erken doğmuş bebeklere ait kolostrumda anlamlı olarak yüksek bulundu (Tablo 2). Zn ve Fe düzeyleri açו- sından ise her iki grup arasında anlamlı fark bulunmadı (Tablo 3,4).

Gestasyonel yaşa göre erken doğmuş bebeklerin anne sütlerinin $\mathrm{Cu}, \mathrm{Zn}$ ve Fe düzeyleri karşılaştıııldığında, 28-30 haftalık grubun kolostrumunun $\mathrm{Cu}$ düzeyi diğer gruplarınkine göre daha düşük, 32-34 haftalık grubun olgun sütünün $\mathrm{Fe}$ düzeyi daha yüksek olarak bulundu (Tablo 5,6). Çinko ise laktasyonun her üç döneminde 2830 haftalık grupta diğer erken doğmuş bebek gruplarına göre daha yüksek bulunurken bu yükseklik sadece geçiş sütünde istatistiksel olarak anlamlı idi (Tablo 7).

Bebeklerin anne sütü ile aldıkları günlük $\mathrm{Cu}, \mathrm{Zn}$ ve $\mathrm{Fe}$ miktarı $\mu \mathrm{g} / \mathrm{kg} / \mathrm{gün}$ olarak hesaplandı. Anne sütü ile alınan $\mathrm{Cu}, \mathrm{Zn}$ ve $\mathrm{Fe}$ miktarının bu elementler için belirlenen RDA'nın $(13,14)$ yüzdesi olarak hesaplandı. Hem zamanında hem de erken doğmuş bebeklerin anne sütü ile beslendiklerinde aldıkları $\mathrm{Cu}, \mathrm{Zn}$ ve Fe miktarı bebekler için belirlenen RDA'nın altındaydı (Tablo 8,9).

Tablo 1. Kayseri'de doğan bebeklerin anne sütlerinin $\mathrm{Cu}$, Fe ve Zn içeriği ve bu elementlerin düzeyinin laktasyon zamanı ile olan değişimi (mg/L) $(\mathrm{n}: 88)$

\begin{tabular}{|l|c|c|c|c|}
\hline & $\begin{array}{c}\text { Kolostrum } \\
\text { ortanca }\end{array}$ & $\begin{array}{c}\text { Geçiş sütü } \\
\text { ortanca }\end{array}$ & $\begin{array}{c}\text { Olgun süt } \\
\text { ortanca }\end{array}$ \\
\hline $\mathrm{Cu}(\mathrm{mg} / \mathrm{L})$ & $0,06(0,00-0,23)^{\mathrm{b}}$ & $0,05(0,01-0,09)^{\mathrm{a}}$ & $0,05(0,01-0,09)$ \\
\hline $\mathrm{Fe}(\mathrm{mg} / \mathrm{L})$ & $1,36(0,44-11,60)^{\mathrm{b}}$ & $1,11(0,11-0,63)^{\mathrm{a}}$ & $1,21(0,18-11,21)$ & 0,026 \\
\hline $\mathrm{Zn} \mathrm{(mg/L)}$ & $2,26(0,01-13,45)^{\mathrm{cb}}$ & $1,89(0,07-5,65)^{\mathrm{a}}$ & $1,00(0,00-1,00)^{\mathrm{a}}$ & $<0,001$ \\
\hline
\end{tabular}

h: hafta, a: kolostrumdan farklı olanı gösterir, b: geçiş sütünden farklı olanı gösterir, c: olgun sütten farklı olanı gösterir

Tablo 2. Zamanında ve erken doğmuş bebek grubunun kolostrum sütlerinin $\mathrm{Cu}$, Fe ve Zn düzeyleri (mg/L)

\begin{tabular}{|l|c|c|c|}
\hline & $\begin{array}{c}\text { Zamanında doğmuş (n:41) } \\
\text { ortanca }\end{array}$ & $\begin{array}{c}\text { Erken doğmuş (n:47) } \\
\text { ortanca }\end{array}$ & p \\
\hline $\mathrm{Cu}$ & $0,06(0,00-0,23)$ & $0,07(0,10-0,16)$ & 0,019 \\
\hline $\mathrm{Fe}$ & $1,13(0,63-3,33)$ & $1,50(0,44-11,60)$ & 0,066 \\
\hline $\mathrm{Zn}$ & $2,61(0,28-11,21)$ & $2,02(0,01-13,45)$ & 0,140 \\
\hline
\end{tabular}

Tablo 3. Zamanında ve erken doğmuş bebek grubunun geçiş sütlerinin Cu, Fe ve Zn düzeyleri (mg/L)

\begin{tabular}{|l|c|c|c|}
\hline & $\begin{array}{c}\text { Zamanında doğmuş (n:41) } \\
\text { ortanca }\end{array}$ & $\begin{array}{c}\text { Erken doğmuş (n:47) } \\
\text { ortanca }\end{array}$ & $\mathbf{p}$ \\
\hline $\mathrm{Cu}(\mathrm{mg} / \mathrm{L})$ & $0,05(0,01-0,08)$ & $0,05(0,01-0,09)$ & 0,387 \\
\hline $\mathrm{Fe}(\mathrm{mg} / \mathrm{L})$ & $1,09(0,59-5,78)$ & $1,12(0,11-6,63)$ & 0,298 \\
\hline $\mathrm{Zn}(\mathrm{mg} / \mathrm{L})$ & $1,90(0,07-3,89)$ & $1,90(0,07-3,89)$ & 0,903 \\
\hline
\end{tabular}

Tablo 4. Zamanında ve erken doğmuş bebek grubunun olgun sütlerinin $\mathrm{Cu}$, Fe ve Zn düzeyleri (mg/L)

\begin{tabular}{|c|c|c|c|}
\hline & $\begin{array}{c}\text { Zamanında doğmuş (n:41) } \\
\text { ortanca }\end{array}$ & $\begin{array}{c}\text { Erken doğmuş (n:47) } \\
\text { ortanca }\end{array}$ & $p$ \\
\hline $\mathrm{Cu}$ (mg/L) & $0,05(0,01-0,09)$ & $0,05(0,01-0,09)$ & 0,474 \\
\hline $\mathrm{Fe}(\mathrm{mg} / \mathrm{L})$ & $1,18(0,36-7,26)$ & $1,27(0,18-11,21)$ & 0,415 \\
\hline $\mathrm{Zn}(\mathrm{mg} / \mathrm{L})$ & $1,87(0,17-5,65)$ & $1,96(0,02-6,20)$ & 0,831 \\
\hline
\end{tabular}




\section{Tartışma}

Kolostrumun içeriği yenidoğan bir bebeğin ilk günlerindeki gereksinimlerine uygun nitelikte olduğundan dolayı geçiş sütü ve olgun süte göre belirgin farklıllk göstermektedir. Kolostrumun protein, sodyum, potasyum, A vitamini, $D$ vitamini, lizozim, laktoferrin, IgA düzeyinin geçiş sütü ve olgun süte göre daha yüksek olduğu bilinmektedir (8). Kolostrumun $\mathrm{Cu}, \mathrm{Zn}$ ve $\mathrm{Fe}$ düzeylerinin geçiş sütü ve olgun süt ile karşılaştııılığı çalışmamızda, daha önce yapılmış olan çalışmalara benzer şekilde (2,15-17), kolostrumun $\mathrm{Cu}, \mathrm{Zn}$ ve $\mathrm{Fe}$ içeriği geçiş sütü ve olgun süte göre daha yüksek bulundu. Ayrıca laktasyonun ilerlemesi ile $\mathrm{Cu}, \mathrm{Zn}$ ve Fe içeriğinde azalma tespit edildi. Çinko düzeyinde olan azalma, Cu ve Fe'e göre daha belirgindi (Tablo 1).
Çalışmamızda zamanında ve erken doğmuş anne sütlerinin $\mathrm{Cu}, \mathrm{Zn}$ ve $\mathrm{Fe}$ düzeyi ölçülerek, bebeklerin sadece anne sütü ile beslendiklerinde bu elementleri yeterli oranda alıp almadıklarının belirlenmesi hedeflendi. Kayseri'de her iki grup annelerin olgun sütlerinin $\mathrm{Cu}$ düzeyi 0,05 $(0,01-0,09) \mathrm{mg} / \mathrm{L}$ olarak literatüre göre belirgin düşük bulundu (Tablo 10). Cu düzeyi Aquilio ve ark.'larının İtalya'da yaptıkları çalışmada (18) 0,26+0,019 mg/L, Al-Awadi ve ark.'Iarının Kuveyt'te yaptıkları çalıșmada (19) 2,68+0,15 mg/L, Mandiç ve ark.'larının Hırvatistan'da yaptıkları çaIışmada (20) 0,51+0,19 mg/L, Sharda ve ark.'larının Hindistan'da yaptıkları çalışmada (21) 0,52+0,03 mg/L olarak bulunmuştur. Ülkemizde yapılan çalışmalara bakıldığında Kösecik ve ark.'larının (22) Urfa'da yaptıkları çalışmada

Tablo 5. Kayseri'de doğan bebeklerin anne sütlerinin $\mathrm{Cu}$, Fe ve Zn içeriği ve bu elementlerin düzeyinin laktasyon zamanı ile olan değişimi $(\mathrm{mg} / \mathrm{L})(\mathrm{n}: 88)$

\begin{tabular}{|l|c|c|c|c|}
\hline & $\mathbf{n}$ & $\begin{array}{c}\text { Kolostrum } \\
\text { ortanca }\end{array}$ & $\begin{array}{c}\text { Geçiş sütü } \\
\text { ortanca }\end{array}$ & $\begin{array}{c}\text { Olgun süt } \\
\text { ortanca }\end{array}$ \\
\hline $28-30^{\mathrm{h}}$ & 10 & $0,05(0,01-0,07)$ & $0,05(0,03-0,07)$ & $0,02(0,02-0,09)$ \\
\hline $30-31^{\mathrm{h}}$ & 12 & $0,08(0,04-13)^{\mathrm{a}}$ & $0,05(0,03-0,07)$ & $0,02(0,02-0,09)$ \\
\hline $32-33^{\mathrm{h}}$ & 10 & $0,08(0,04-0,16)^{\mathrm{a}}$ & $0,07(0,05-0,08)$ & $0,06(0,04-0,08)$ \\
\hline $34-36^{\mathrm{h}}$ & 15 & $0,06(0,04-0,12)^{\mathrm{a}}$ & $0,05(0,04-0,09)$ & $6(0,03-0,09)$ \\
\hline $\mathrm{p}$ & - & 0,002 & 0,230 & 0,208 \\
\hline
\end{tabular}

h: hafta, a: 28-30 haftalık gruptan farklı olanı gösterir, b: 30-32 haftallk gruptan farklı olanı gösterir, c: 32-34 haftalık gruptan farklı olanı gösterir, d: 34-36 haftalık gruptan farklı olanı gösterir

Tablo 6. Gestasyonel yaşa göre erken doğmuş bebek grubundaki annelerin kolostrum, geçiş ve olgun sütlerinin Fe düzeyleri (mg/L)

\begin{tabular}{|l|c|c|c|c|}
\hline & $\mathbf{n}$ & $\begin{array}{c}\text { Kolostrum } \\
\text { ortanca }\end{array}$ & $\begin{array}{c}\text { Geçiş sütü } \\
\text { ortanca }\end{array}$ & $\begin{array}{c}\text { Olgun süt } \\
\text { ortanca }\end{array}$ \\
\hline $28-20^{\mathrm{h}}$ & 10 & $0,98(0,44-2,32)$ & $0,85(0,40-6,63)$ & $1,05(0,18-1,96)^{\mathrm{c}}$ \\
\hline $30-32^{\mathrm{h}}$ & 12 & $1,65(0,67-11,60)$ & $1,07(0,11-2,88)$ & $0,97(0,68-3,02)^{\mathrm{c}}$ \\
\hline $32-34^{\mathrm{h}}$ & 10 & $1,67(1,10-2,40)$ & $1,30(0,84-5,57)$ & $1,99(1,73-11,21)^{\mathrm{a}, \mathrm{b}, \mathrm{d}}$ \\
\hline $34-36^{\mathrm{h}}$ & 15 & $1,64(0,80-3,82)$ & $1,21(0,83-3,18)$ & $1,12(0,72-4,03)^{\mathrm{c}}$ \\
\hline $\mathrm{p}$ & - & 0,136 & 0,393 & 0,001 \\
\hline
\end{tabular}

h: hafta, a: 28-30 haftalık gruptan farklı olanı gösterir, b: 30-32 haftalık gruptan farklı olanı gösterir, c: 32-34 haftalık gruptan farklı olanı gösterir, d: 34-36 haftalık gruptan farklı olanı gösterir

Tablo 7. Gestasyonel yaşa göre erken doğmuş bebek grubundaki annelerin kolostrum, geçiş ve olgun sütlerinin Zn düzeyleri

\begin{tabular}{|l|c|c|c|c|}
\hline & $\mathbf{n}$ & $\begin{array}{c}\text { Kolostrum } \\
\text { ortanca }\end{array}$ & $\begin{array}{c}\text { Geçiş sütü } \\
\text { ortanca }\end{array}$ & $\begin{array}{c}\text { Olgun süt } \\
\text { ortanca }\end{array}$ \\
\hline $28-30^{\mathrm{h}}$ & 11 & $3,10(1,33-5,07)$ & $3,87(2,81-4,99)^{\mathrm{b}, \mathrm{c}, \mathrm{d}}$ & $3,00(0,27-5,58)$ \\
\hline $30-32^{\mathrm{h}}$ & 12 & $1,99(0,28-7,60)$ & $0,47(0,21-3,09)^{\mathrm{a}}$ & $2,14(0,02-4,92)$ \\
\hline $32-34^{\mathrm{h}}$ & 10 & $0,09(0,01-13,45)$ & $0,39(0,17-3,57)^{\mathrm{a}}$ & $0,68(0,11-4,42)$ \\
\hline $34-36^{\mathrm{h}}$ & 15 & $1,0932(0,10-7,00)$ & $0,85(0,18-5,65)^{\mathrm{a}}$ & $1,00(0,08-4,07)$ \\
\hline$p$ & - & 0,078 & 0,001 & 0,132 \\
\hline
\end{tabular}

h: hafta, a: 28-30 haftalık gruptan farklı olanı gösterir, b: 30-32 haftalık gruptan farklı olanı gösterir, c: $32-34$ haftalık gruptan farklı olanı gösterir,

d: 34-36 haftalık gruptan farklı olanı gösterir 
Cu düzeyi çalışmamıza benzer şekilde 0,04 $\pm 0,002 \mathrm{mg} / \mathrm{L}$ olarak düşük iken, Atıcı ve ark.' 'larının (23) Adana 'da yaptıkları çalışmada literatüre benzer şekilde $0,28 \pm 0,08 \mathrm{mg} / \mathrm{L}$ olarak bulunmuştur. Yoshinaga ve ark.'larına (7) göre anne sütündeki eser elementlerin düzeyi hakkında farklı ülkelerde yapılmış olan çalışmalarda birbirinden oldukça farklı sonuçların bulunması anne sütünün eser element düzeyi üzerinde coğrafi farklılı̆ın etkisinin belirgin olduğunu düşündürmektedir.

Anne sütünün $\mathrm{Cu}$ içeriği anne diyetinden etkilenmemekte ve anneye $\mathrm{Cu}$ desteği yapılması ile anne sütünün Cu düzeyinde artma görülmemektedir $(1,3,6,24)$. Schramel ve ark.'larının (6) eş zamanlı olarak anne sütünün, plesentanın, anne ve bebek serumunun $\mathrm{Zn}, \mathrm{Cu}$ ve $\mathrm{Fe}$ düzeyini belirleyerek yaptıkları çalışmada, anne sütü ile anne serumunun Zn, Cu ve Fe düzeyi arasında ilișki saptanmamıştır. Bu yüzden çalışmamızda annelerin aldığı diyet ve anne serumunun $\mathrm{Zn}$, Cu ve Fe düzeyi sorgulanmadı. Anne sütünün protein miktarı eser elementlerin düzeyini ve biyoyararlanımını etkilemektedir. Al-Awadi ve ark.'larının (19) yaptıkları çalışmada total serum proteinlerinin ve anne sütünün protein miktarının azalması ile eser element düzeyinde azalma tespit edilmiştir. Anne sütünün protein içeriği anne diyeti ile doğrudan ilişkili olduğundan (25), proteinden fakir beslenme, anne sütünün protein içeriğinde azalmaya yol açarak anne sütünün $\mathrm{Cu}$ düzeyinde dolaylı olarak düşmeye neden olabilir. Anne sütünün $\mathrm{Cu}$ düzeyi ile beraber, anne sütünün ve serumunun protein içeriği çallşıldığı ileri bir çalışma ile Kayseri' deki annelerin sütlerinin Cu düzeyinin düşük olmasının nedeni araştırılabilir.
Fetüste Cu birikimi son üç ayda gerçekleştiğinden dolayı erken doğmuş bebeklerin doğduklarında Cu depoları yetersizdir (26). Anne sütünün Cu düzeyi bebeklerin günlük gereksinimlerine göre düşük olduğundan erken doğan bebekler yaşamlarının ilk günlerinde negatif dengeye girmekte, hem depolarının yetersiz olması hem de seruloplazmin düzeylerinin düşük olması nedeniyle bakır eksikliği gelişebilmektedir (27). Bu bebeklerde hipotoni, demir tedavisine dirençli anemi, nötropeni, osteoporoz ve kendiliğinden kemik kırıkları gibi ciddi komplikasyonlar görülebilmektedir (28). Çalışmamıza göre Kayseri'de anne sütü ile beslenen erken doğmus bir bebek günlük ortalama 150$200 \mathrm{ml} / \mathrm{kg}$ anne sütü aldığında $0,01 \mathrm{mg} / \mathrm{kg} / \mathrm{gün} \mathrm{Cu}$ almakta, bu değer bebekler için belirlenen RDA'nın (13) \%8,3'üne karşılık gelmektedir (Tablo 8). Dolayısı ile Kayseri'de anne sütü ile beslenen erken doğmuş bebeklerde bakır eksikliği gelişmesi muhtemeldir. Anne sütünün $\mathrm{Cu}$ içeriği ile beraber erken doğmuş bebeklerin serum Cu düzeyinin belirlendiği ileri bir çalışma ile sadece anne sütü ile beslenen erken doğmuş bebeklerde bakır eksikliğinin gelişip gelişmediği belirlenebilir. Çalışmamızdaki verilere dayanılarak Kayseri'de doğan tüm erken doğmuş bebeklere Cu desteği yapılması gerektiği söylenebilir.

Çalışmamıza göre Kayseri'de anne sütü ile beslenen zamanında doğmuş bir bebek günlük $750 \mathrm{ml}$ anne sütü aldığında $0,04 \mathrm{mg} / \mathrm{gün} \mathrm{Cu}$ almaktadır. Bu term bebekler için belirlenen RDA'nın (14) \%20'sine karşılık gelmektedir (Tablo 9). Zamanında doğmuş bebeklerin doğumda bakır depoları yeterli olduğundan, anne sütü ile beslenen bu bebeklerde $\mathrm{Cu}$ eksikliği bildirilmemiştir. Bu nedenle Kay-

Tablo 8. Erken doğmuş bebeklerin anne sütlerinin eser element düzeyi ile erken doğmuş yenidoğanların günlük gereksinimlerinin karşılaştırılması

\begin{tabular}{|l|c|c|c|c|}
\hline & $\begin{array}{c}\text { Anne sütündeki } \\
\text { düzey } \\
\mathbf{m g} / \mathbf{L}\end{array}$ & $\begin{array}{c}\text { Anne sütü ile* } \\
\text { alınan miktar } \\
\mathbf{m g} / \mathbf{k g} / \mathbf{g u ̈ n}\end{array}$ & $\begin{array}{c}\text { RDA** } \\
\text { mg/kg/gün }\end{array}$ & $\begin{array}{c}\text { RDA*** } \\
\%\end{array}$ \\
\hline $\mathrm{Cu}$ & 0,05 & 0,01 & $0,12-0,15$ & 8,3 \\
\hline $\mathrm{Zn}$ & 1,96 & 0,39 & 1 & 39,2 \\
\hline $\mathrm{Fe}$ & 1,27 & 0,25 & 2 & 12,7 \\
\hline
\end{tabular}

* Erken doğmuş bir yenidoğanın günlük 150-200 ml/kg/gün anne sütü aldığı varsayılarak hesaplanmıştır.

** International Concensus Recommendation, Tsang et al. 1993 (13)

*** Çalışmamıza alınan erken doğmuş bebeklerin anne sütü ile aldıkları eser element miktarlarıın RDA'ya göre yüzdesi

Tablo 9. Zamanında doğmuş bebeklerin anne sütlerinin eser element düzeyi ile bu yenidoğanların günlük gereksinimlerinin karşılaştırılması

\begin{tabular}{|c|c|c|c|c|}
\hline & $\begin{array}{c}\text { Anne sütündeki } \\
\text { düzey } \\
\text { mg/L }\end{array}$ & $\begin{array}{l}\text { Anne sütü ile* } \\
\text { alınan miktar } \\
\text { mg/kg/gün }\end{array}$ & $\begin{array}{c}\text { RDA }^{* *} \\
\mathrm{mg} / \mathrm{kg} / \mathrm{gün}\end{array}$ & $\begin{array}{l}\text { RDA }^{\star \star * *} \\
\%\end{array}$ \\
\hline $\mathrm{Cu}$ & 0,05 & 0,04 & 0,20 & 20 \\
\hline $\mathrm{Zn}$ & 1,87 & 1,40 & 2 & 70 \\
\hline $\mathrm{Fe}$ & 1,18 & 0,89 & 0,27 & 300 \\
\hline
\end{tabular}

* Erken doğmuș bir yenidoğanın günlük 150-200 ml/kg/gün anne sütü aldığı varsayılarak hesaplanmıștır.

** International Concensus Recommendation, Tsang et al. 1993 (13)

*** Çalışmamıza alınan erken doğmuş bebeklerin anne sütü ile aldıkları eser element miktarlarının RDA'ya göre yüzdesi 
seri'de zamanında doğmuş bebeklere destek gerekmeyebilir. Anne sütü ile alınan Cu miktarının bebeklerin günlük gereksinimlerinin altında olmasına rağmen bebeklerin gelişimlerinin normal olması RDA'nın yeniden gözden geçirilmesinin gerektiği şeklinde yorumlanabilir.

Çalışmamızda erken doğmuş bebeklerin annelerin olgun sütlerinin $\mathrm{Zn}$ düzeyi literatüre benzer şekilde 1,96 $(0,02-6,20) \mathrm{mg} / \mathrm{L}$ olarak bulundu (Tablo 10). Birçok araştırmacıya göre anne sütünün $\mathrm{Zn}$ düzeyi anne diyetinden etkilenmemekte, anneye $Z n$ desteği yapılması ile anne sütünün Zn düzeyinde artma görülmemektedir $(1,3,6)$. Krebs ve ark.'larına göre ise (29) anneye Zn desteği yapılması ile anne sütündeki $\mathrm{Zn}$ düzeyi arttırılabilir. Fetüste $\mathrm{Zn}$ birikimi son üç ayda gerçekleştiğinden ve laktasyonun ilerlemesi ile anne sütünün $\mathrm{Zn}$ düzeyi belirgin olarak azaldığından dolayı erken doğmuş bebeklerde laktasyonun 2-4. aylarında Zn eksikliği görülebilmektedir (30). Prasad ve ark.'larına (31) göre anne sütü ile beslenen yenidoğanlarda anne sütünün $\mathrm{Zn}$ düzeyinin düşük olması nedeni ile $\mathrm{Zn}$ eksikliği gelişebilmekte, bu yenidoğanlarda büyümede duraklama, alopesi, ishal, el ve ayaklarda vezilülopüstüler lezyonlar, ağız çevresi, yüzde ve anüs etrafında görülebil-

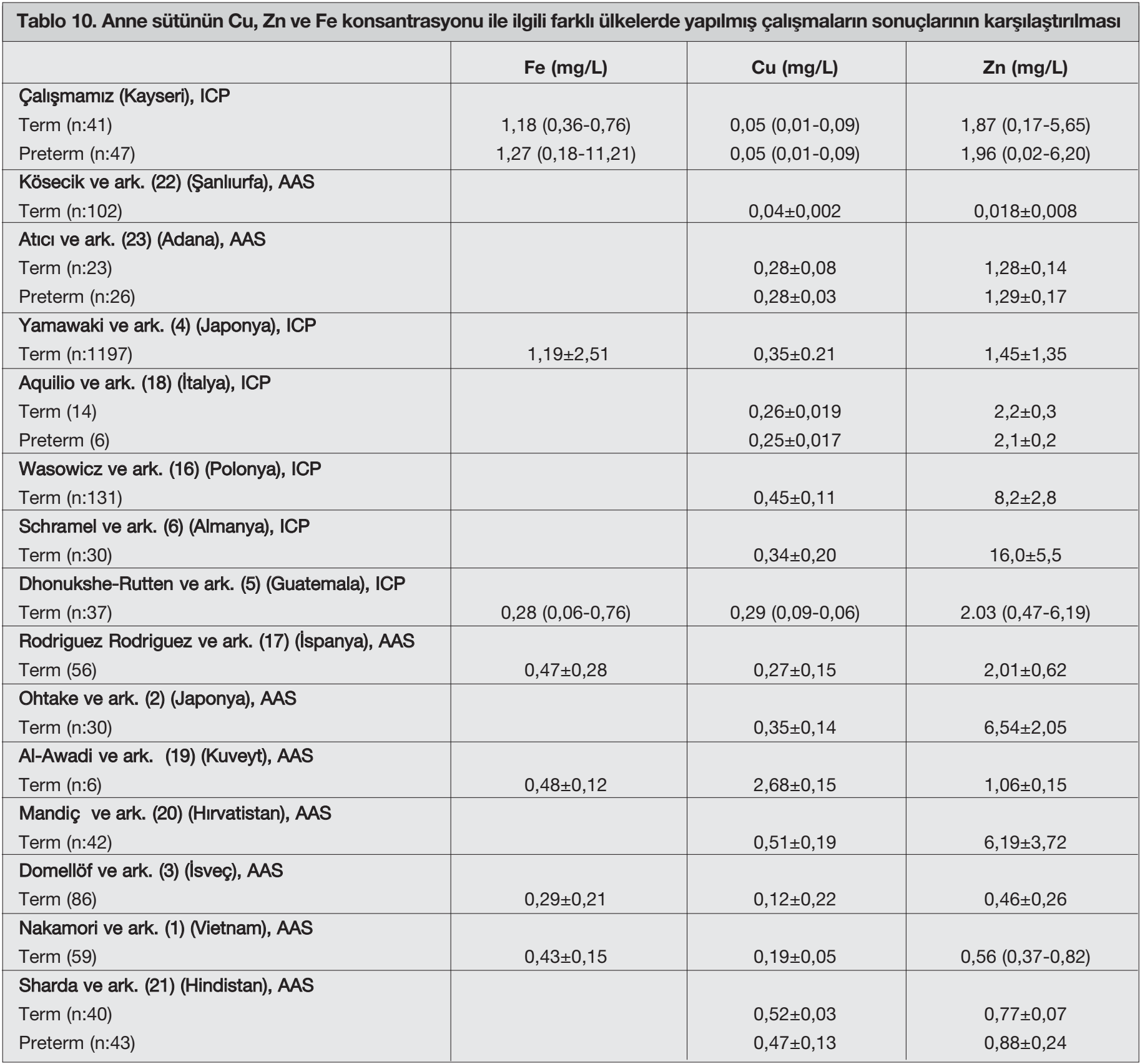

AAS : Atomic Absorption Spectrometry

ICP : Inductively Coupled Plasma Atomic Emission Spectroscopy 
mektedir. Çalışmamıza göre Kayseri'de anne sütü ile beslenen erken doğmuş bir bebek günlük ortalama 150-200 $\mathrm{ml} / \mathrm{kg}$ anne sütü aldığında 0,39 mg/kg/gün Zn almakta, bu değer RDA'nın (13) \%39,2'sine karşılık gelmektedir. (Tablo 8). Dolayısıyla Kayseri'de sadece anne sütü ile beslenen erken doğmuş bebeklerde Zn eksikliği gelişmesi olasıdır ve anne sütü ile beslenen bu bebeklere $\mathrm{Zn}$ desteği yapılması gerektiği söylenebilir.

Zamanında doğmuş bir bebek ise günlük $750 \mathrm{ml}$ anne sütü aldığında 1,4 mg/gün Zn almakta, bu değer RDA'nın (14) \%70'ine karşılık gelmektedir (Tablo 9). Zamanında doğmuş bebeklerin doğumda Zn depoları yeterli olduğundan, anne sütü ile beslenen bu bebeklerde Zn eksikliği bildirilmemiştir (31). Dolayısı ile Kayseri'de sadece anne sütü ile beslenen zamanında doğmuş bebeklere $\mathrm{Zn}$ desteği yapılması gerekmeyebilir.

Çalışmamızda erken doğmuş bebeklerin annelerinin olgun sütlerinin $\mathrm{Fe}$ içeriği literatüre benzer şekilde 1,27 $(0,18-11,21) \mathrm{mg} / \mathrm{L}$ olarak bulundu. Birçok araştırmacıya göre göre anne sütünün Fe içeriği anne diyetinden etkilenmemekte, anneye Fe desteği yapılması ile anne sütünün Fe yoğunluğunda artma görülmemektedir (1,3,6,24).

Doğumdaki Fe depoları bebeğin gestasyonel yaşına, bebeğin doğum ağırlığına, anneden plesenta aracılığı ile olan geçişe bağlıdır. Demir depoları ilk 6-8 hafta yeterli olsa da 12. haftadan sonra destek yapılmayan erken doğmuş yenidoğanların Fe depoları hızla azalmakta ve Fe eksikliği gelişmektedir. Bu nedenle erken doğmuş bebeklere ilk iki aydan, zamanında doğmuş bebeklere ise 6. aydan sonra Fe verilmesi gerekmektedir (30). Çalışmamıza göre Kayseri'de anne sütü ile beslenen erken doğmuş bir bebek günlük ortalama 150-200 ml/kg anne sütü aldığında $0,25 \mathrm{mg} / \mathrm{kg} / \mathrm{gün} \mathrm{Fe}$ almakta, bu değer bebekler için belirlenen RDA'nın (13) \%12,7'sine karşılık gelmektedir (Tablo 8). Zamanında doğmuş bir bebek ise günlük 750 $\mathrm{ml}$ anne sütü aldığında 0,89 mg/gün Fe almakta ve bu değer RDA'nın (14) \%300'üne karşılık gelmektedir (Tablo 9). Çalışmamızın sonuçlarına dayanılarak Kayseri'de anne sütü ile beslenen zamanında doğmuş bebeklere Fe desteğinin gerekmediği, erken doğanlara ise depoların yetersiz olması ve anne sütünün Fe içeriğinin düşük olması nedeni ile erken dönemde Fe desteği yapılması gerektiği söylenebilir.

Erken doğmuş bebeklerin anne sütleri meme dokusunun fizyolojik, metabolik ve endokrin olarak olgunlaşmamış olmasından dolayı zamanında doğmuş bebeğin anne sütüne göre farklılık göstermektedir (9). Erken ve zamanında doğmuş bebeklerin anne sütlerinin eser element içeriğinin karşılaştırıldığı çalışmalarda birbirinden oldukça farkI sonuçlara varılmıştır. Örneğin Perrone ve ark.' larının (15) çalışmasında Cu ve Zn düzeyi erken doğmuş bebeğin annesinin olgun sütünde zamanında doğmuş bebeğin annesinin olgun sütüne göre daha düşük, Fe içeriği erken doğmuş bebeğe ait kolostrum sütünde zamanında doğmuş bebeğe ait kolostrum sütüne göre daha yüksek olarak bulunmuştur. Hamalatha ve ark.'larının (32) çalışmasında
Zn düzeyi laktasyonun her üç döneminde erken doğmuş bebeklerin anne sütlerinde zamanında doğmuş bebeklerin anne sütlerine göre daha yüksek olarak bulunmuştur. Aquillo ve ark.'larının (18) çalışmasında her iki grup anne sütlerinin $\mathrm{Cu}, \mathrm{Fe}, \mathrm{Zn}$ düzeyleri arasında anlamlı fark tespit edilmemiştir.

Bizim çalışmamızda, Cu erken doğmuş bebeğe ait kolostrumda daha yüksek olarak bulundu (Tablo 2), Zn ve Fe açısından ise her iki grup arasında farklılık gözlenmedi (Tablo 3,4).

Gestastonel yaşla anne sütünün içeriği değişebilmektedir. Örneğin gestasyonel yaş anne sütünün protein içeriğini belirleyen en önemli etmendir. Gestasyonel yaş azaldıkça anne sütünün protein içeriği artmakta, karbonhidrat içeriği ise azalmaktadır (33). Çalışmamızda eser elementler üzerinde yapılmış önceki çalışmalardan farklı olarak erken doğmuş bebeklerin anne sütleri, bebeklerin gestasyonel yaşlarına göre ayrıca değerlendirildi. Buna göre 28-30 haftalık grubun kolostrumunun $\mathrm{Cu}$ içeriği daha düşük (Tablo 5) ve 32-34 haftalık grubun olgun sütünün Fe içeriği diğerlerine göre daha yüksekti (Tablo 6). Yirmi sekiz-30 haftalık grubun Zn içeriği laktasyonun her üç zamanında diğer gruplara göre daha yüksek bulunurken bu yükseklik sadece geçiş sütünde istatistiksel olarak anlamlıydı (Tablo 7). Çinko düzeyinin 28-30 haftalık grupta yüksek olması Zn'nin büyüme gelişme üzerinde olan olumlu etkileri nedeni ile olabilir.

Sonuç olarak, erken ve zamanında doğmuş bebeklerin anne sütlerinin $\mathrm{Fe}, \mathrm{Cu}, \mathrm{Zn}$ içeriğinin belirlendiği çalışmamızın sonuçlarına göre, bölgemizde yaşayan annelerin sütlerinin Cu düzeyi oldukça düşüktür. Çinko ve Fe düzeyi literatüre göre düşük olmamasına rağmen bebeklerin günlük gereksinimlerini karşılayamamaktadır. Anne sütüyle beslenen erken doğmuş bebeklere her üç element açısından destek gerekmektedir. Aynı durum zamanında doğmuş bebekler için söz konusu olsa da depolarının yeterli olmasından dolayı bu bebeklere erken dönemde destek gerekmeyebilir. Ayrıca zamanında doğmuş bebeklerin destek almamasına rağmen gelişimlerinin normal olması eser elementler için belirlenen RDA'nın yüksek olduğu ve tekrar gözden geçirilmesi gerektiği şeklinde yorumlanabilir. Anne sütünün $\mathrm{Cu}, \mathrm{Zn}$ ve Fe düzeyi üzerinde gestasyonel yaşın etkisi belirgindir. 28-30 haftalık bebeklerin anne sütlerinin $\mathrm{Cu}$ düzeyinin düşük ve $\mathrm{Zn}$ düzeyinin yüksek olması ileri derecede erken doğmuş yenidoğanlar için hazırlanan formül mamalarda dikkate alınabilir.

\section{Kaynaklar}

1. Nakamori M, Ninh NX, Isomura $\mathrm{H}$, et al. Nutritional status of lactating mothers and their breast milk concentration of iron, zinc and copper in rural Vietnam. J Nutr Sci Vitaminol 2009; 55:338-45. (Abstract)/PDA

2. Ohtake M, Tamura T. Changes in zinc and copper concentrations in breast milk and blood of Japanese women during lactation. J Nutr SCI Vitaminol 1992; 39:189-200. Abstract 
3. Dömellöf M, Lonnerdal B, Dewey KG, Cohen RJ, Hemell O. Iron, zinc, and copper concentrations in breast milk are independent of maternal mineral status. Am J Clin Nutr 2004; 79:111-5. Abstrac/ Full Tex/PDA

4. Yamawaki N, Yamada M, Kan-no T, et al. Macronutrient, mineral and trace element composition of breast milk from Japanese women. J Trace Elem Med Biol 2005; 19:171-81. (Abs(tract) / PDH

5. Dhonukshe-Rutten RA, Vossenaar M, West CE, et al. Day-to-day variations in iron, zinc and copper in breast milk of Guatemalan mothers. J Pediatr Gastroenterol Nutr 2005; 40:128-34. Full Tex

6. Schramel P, Lill G, Hasse S, et al. Mineral and trace element concentrations in human breast milk, placenta, maternal blood, and the blood of the newborn. Biol Trace Elem Res 1988; 16:67-75. Abstract / Eull Tex

7. Yoshinaga J, Li JZ, Suzuki T, et al. Trace elements human transitory milk. variation caused by biological attributes of mother and infant. Biol Trace Elem Res 1991; 31:159-70. Abstract

8. Coşkun T. Anne sütü ile beslenme. Katkı Pediatri Dergis 2003; 25:163-183.

9. Anderson $\mathrm{GH}$. The effect of prematurity on milk composition and its physiological basis. Fed Proc 1984; 43:2438-42. Abstract / Eull Tex

10. Coppa GV, Pierani $P$, Zampini L, et al. Lactose, oligosaccharide and monosaccharide content of milk from mothers delivering preterm newborns over the first month of lactation. Minerva Pediatr 1997; 49:471-5. Abstract Eull Tex

11. Faerk J, Skafte L, Petersen S, et al. Macronutrients in milk from mothers delivering preterm. Adv Exp Med Biol 2001; 501:409-13. Abstract

12. Charpak N, Ruiz JG; KMC Team. Breast milk composition in a cohort of pre-term infants mothers followed in an ambulatory programme in Colombia. Acta Paediatr 2007; 96:1755-9. Abstract / Full Tex / PDF

13. Tsang RC, Lucas $A$, Uauy $R$, et al. Nutritional needs of the preterm infant. İn: Tsang (ed), Scientific basis and practical guidelines. Caduceus Medical Publishers, New York, 1993, pp.228-89.

14. Türkiye'ye özgü beslenme rehberi. In. TC Sağlık Bakanlığı Temel Sağlık Hizmetleri Genel Müdürlüğü. Hacettepe Üniversitesi Beslenme ve Diyetetik Bölümü (1st ed). Gökçe Ofset, Ankara 2004, pp.59.

15. Perrone L, Di Palma L, Di Toro R, Giolanella G, Moro R. Interaction of trace elements in a longitudinal study of human milk from full-term and preterm mothers. Biol Trace Element Res 1994; 41:321-30. (Abstract)

16. Wasowicz W, Gromadzinska J, Szram K, et al. Selenium, zinc, and copper concentrations in the blood and milk of lactating women. Biol Trace Elem Res 2001; 79:221-33. Abstract / Eull Text
17. Rodriguez Rodriguez EM, Sanz Alaejos M, Diaz Romero C. Concentrations of iron, copper and zinc in human milk and powdered infant formula. Int J Food Sci Nutr 2000; 51:373-80. [Abstract] / Eull Text]

18. Kösecik M, Söyler H, Kocyigit $A$, ve ark. Anne sütü çinko bakır ve demir konsantrasyonlarının sosyoekonomik düzeyle ilişkisi. Yeni Tıp Dergisi 1999; 16:262-4.

19. Atıcı $A$, Yılmaz $M$, Satar $M$, ve ark. Prematür ve matür anne sütünün mineral ve eser element içeriği. Çocuk, Sağlığı ve Hastalıkları Dergisi 1996; 39:457-64.

20. Mandiç Z, Mandiç ML, Grgiç J, et al. Copper and zinc content in human milk in Croatia. Eur J Epidemiol 1997 ;13:185-8. Full Tex]/ PDD

21. Sharda B, Bhandari B, Bhandari LM. Copper, zinc, magnesium and cadmium levels of breast milk of Indian women. Trans R Soc Trop Med Hyg 1983; 77:201-3. Abstract / PDF

22. Moser PB, Reynolds RD, Acharya S, Howard MP, Andom MB, Lewis SA. Copper, iron, and selenium dietary intake and status of Nepalese lactating women and their breast-fed infants. Am j Clin Nutr 1988; 47:729-34. [Abstract / PDF]

23. Al-Awadi FM, Srikumar TS. Trace-element status in milk and plasma of Kuwaiti and non-Kuwaiti lactating mothers. Nutrition. 2000; 16:1069-73. Abstrac / Full Tex / PD

24. Lonnerdal B. Effects of maternal dietary intake on human milk composition. J Nutr 1986; 116:499-513. (Abstract / PDF

25. Castillo-Duran C, Cassorla F. Trace minerals in human growth and development. J Pediatr Endocrinol Metab 1999; 12:589601. (Abstract)

26. Pontz BF, Herwig J, Greinacher I. Cu deficiency as a cause of spontaneous fracture in a premature infant. Monatsschr Kinderheilkd 1989; 137:419-21. Abstract

27. Sutton AM, Harvie A, Cockburn F, Farguharson J, Logan RW. Copper deficiency in the preterm infant of very low birthweight. Four cases and a reference range for plasma copper. Arch Dis Child 1985; 60:644-51. Abstract/[Full Tex)/[PDF)

28. Krebs NF. Zinc supplementation during lactation. Am J Clin Nutr 1998; 68:509-12. Abstract / PDF)

29. Fertwell M, Lucas A. Infant feding. In: Janet M, Rennie MA (eds). Robertson's Textbook of Neonatology (4 th ed) Elsevier Churchill Livingstone, China 2005, pp.281-314.

30. Prasad AS. Zinc in women, infants and children. J Am Coll Nutr 1996; 15:113-20. [Abstract)

31. Hemalatha P, Bhaskaram P, Kumar PA, Khan MM, Islam MA. Zinc status of breastfed and formula-fed infants of different gestational ages. J Trop Pediatr 1997; 43:52-4. [Abstract PDF]

32. Aquilio E, Spagnoli R, Seri S, Bottone G, Spennati G. Trace element content in human milk during lactation of preterm newborns. Biol Trace Elem Res 1996; 51:63-70. Abstrac / Eull Text

33. Faerk J, Skafte L, Petersen S, Peitersen B, Michaelsen KF. Micronutrients in milk from mothers delivering pterm. Adv exp Med Biol 2001; 501: 409-13. (Abstract) 